\title{
Does the Internet make people happier?
}

\author{
Thierry Pénard, Nicolas Poussing and Raphaël Suire* \\ July, 15, 2013
}

\begin{abstract}
Given the increasingly prominent role the Internet plays in people's daily life, understanding its influence on individual well-being is crucial. Internet use yields direct utility and economic returns that may increase life satisfaction. But the Internet might also have detrimental effects (e.g. addiction, social isolation). This paper aims to examine the impact of Internet use on individual well-being. Using Luxemburgish data extracted from the European Value survey, we find evidence that non users are less satisfied in their life than Internet users. Moreover, the positive influence of Internet use is stronger for individuals who are young or not satisfied with their income. These findings suggest that public policies aiming to reduce the digital divide by reaching out to non-Internet users are socially desirable.
\end{abstract}

Keywords: Internet, happiness, life satisfaction, digital divide, social capital, social values.

JEL code: D12; D6, L86, Z13

\footnotetext{
* Pénard: Professor of Economics, University of Rennes 1, CREM (CNRS), 7 place Hoche, 35065 Rennes Cedex, France. thierry.penard@univ-rennes1.fr. Poussing: Research Fellow, CEPS/INSTEAD, 3, avenue de la Fonte, L-4364 Esch-sur-Alzette, Luxembourg, nicolas.poussing@ceps.lu. Suire: Associate professor of Economics, University of Rennes 1, CREM (CNRS), 7 place Hoche, 35065 Rennes Cedex, France. raphael.suire@univ-rennes1.fr
} 


\section{INTRODUCTION}

Recent surveys have shown that in developed countries, most people regularly use the Internet ${ }^{1}$. For young people, the Internet is the primary media choice and has passed the television in the amount of time spent a week. Given the increasingly prominent role the Internet plays in people's daily life, understanding its influence on individual well-being is crucial. However, this question has received limited attention from scholars. This paper aims to fill this gap by examining whether Internet use increases or decreases life satisfaction.

Several arguments are in favor of a positive influence of the Internet. First, the Internet gives access to a wide range of applications and services that provide direct and indirect benefits (Hong, 2007). It is obvious for online entertainment services (music, video, games ...) that are a source of enjoyment. But thanks to the Internet, people can also save time or money: they can search and process information more efficiently, get better deals, or find products and services that better match their needs, etc. ${ }^{2}$ For all these reasons, the Internet enables individuals to attain a higher level of utility and increase their well-being. Goolsbee and Klenow (2006) estimated the yearly value per consumer derived from Internet access to $\$ 3,000$. Another argument that pleads in favor of a positive impact of Internet use on life satisfaction is that many Internet applications (social networking, emailing, blogging, etc.) have the features of a relational good (i.e. a good that is enjoyed only when it is shared with friends or family members (Uhlaner, 1989)). Since the consumption of relational goods is

\footnotetext{
${ }^{1} 85 \%$ of american adults are Internet users. For american teens (12-17), 95\% are using the Internet (Source Pew Research Survey 2013). In the European Union (27 countries), $70 \%$ of the individuals are using the Internet at least once a week. This propotion is higher (93\%) among the 16-24. (Source Eurostat http://epp.eurostat.ec.europa.eu/portal/page/portal/information_society/publications)

2 For instance, Pope and Kroft (2012) show that the online classifieds site Craiglist has significantly improved the functioning of the housing market in the U.S.A, and caused a reduction in the apartment and housing rental vacancy rate.
} 
source of happiness (Bruni and Stanca, 2008; Gui and Stanca, 2010), Internet use can improve well-being by increasing the time dedicated to relational activities.. In the same vein, the Internet is a means of building and maintaining social relations or social capital ${ }^{3}$ (Franzen, 2003; Penard and Poussing, 2010; Shklovski, Kiesler and Kraut, 2006). Individuals can complement their face-to-face interactions with their family and friends with computermediated interactions. They can also interact online with people they have never met physically, make new "virtual friends" and sometimes find their future spouse. Consequently, online activities can generate more well-being by improving and expanding social capital insofar as social capital is known as a main influential factor of happiness (Helliwell, 2003). For instance, Ellison et al. (2007) find that Facebook enables college students to accumulate social capital (by converting latent ties into weak ties) and thus reinforces their self-esteem and well-being (see also Steinfield et al. 2008). Castronova and Wagner (2011) also show that Second life users report greater satisfaction from their virtual life than from their real life

Another reason to presume a positive relation between Internet use and happiness is that nowadays having access to the Internet is perceived as a social norm in developed countries. Non Internet users could feel ostracized or socially excluded even if they do not feel the desire to adopt the Internet.

However, Internet use might also have detrimental effects. Kraut et al. (2002) find that Internet use increases social interactions with friends and kin only for people rich in social capital. For people who have few friends, Internet use tends to strengthen social isolation. The

\footnotetext{
${ }^{3}$ Social capital refers to the individual's collection of social ties that provide access to resources, information or assistance and from which one can derive market and non-market benefits (better social status, better educational and professional achievement, more happiness, etc.) (Glaeser et alii, 2002; Pénard and Poussing, 2010). At a community or country level, social capital refers to the degree of trust and informal values or norms shared among citizens or community members that permit them to cooperate easily with one another (Putnam, 2000).

${ }^{4}$ Bellou (2013) shows that the diffusion of the Internet (and the development of online dating services) have significantly increased marriage rates among 21-30 year olds in the U.S.A.
} 
time spent online can actually reduce the time available for face-to-face interaction (Nie, Hillygus and Erbring, 2002) and have the same negative impact on happiness as watching TV (Frey, Benesch and Stutzer, 2007). Indeed Lee et al. (2011) show that only face-to-face communication with friends and relatives has a positive effect on the perceived quality of life. They conclude that computer-based communication cannot replace traditional sociability ${ }^{5}$. Another argument is that the Internet could rise social and material aspirations and reduce life satisfaction by creating more individual frustration. This effect has been observed for TV viewers (Bruni and Stanca, 2006) and could be stronger for Internet users because the unlimited quantity and variety of goods available on the Internet increase the desire to consume. Moreover, social network sites, like Facebook, can create envy and bitterness because people are exposed to happiness and positive images of their friends. By social comparison, they could feel more depressed. The Internet might also create addictive behavior (gambling, online gaming, pornography, e.g.) and be detrimental to mental health (Li and Chung, 2006). Some online services can have ambiguous effect since intense use of Craiglist may promote risky behaviors and increase Sexual Transmission Diseases (Chan, Ghose, 2012).

Few studies have investigated the impact of the Internet on happiness, but all of them agree that the Internet has welfare effects. Kavetsos and Koutroumpis (2011) analyze the impact of information technology on subjective well-being, using a pooled cross-sectional data set of European countries. They find that having a cell phone, a PC or an Internet connection at home is associated with higher levels of well-being. Living in a country with a high rate of mobile and Internet users improves life satisfaction as well ${ }^{6}$. Similarly, using an Italian

\footnotetext{
${ }^{5}$ See also Helliwell and Huang (2013) who show that the number of real friends and the frequency of offline meeting with one's friends have a significant positive effect on happiness whereas the number of Facebook friends has no impact.

${ }^{6}$ See also the report published by BCS (The Chartered Institute for IT by Trajectory Partnership) and entitled "The Information Dividend: Why IT makes you 'happier"'. This study shows that Internet use has a positive impact on happiness. Moreover, people with lower incomes or with fewer educational qualifications and women
} 
household survey from 2008, Sabatini (2011) finds a positive relation between online shopping and subjective well-being. Using a survey of 7,000 retired persons, Ford and Ford (2009) show that Internet use by elderly Americans leads to about a $20 \%$ reduction in depression; in other words, the Internet increases their mental well-being. However, these studies have some limitations. Ford and Ford (2009) consider a very specific population (retired people), whereas Kavetsos and Koutroumpis (2011) investigate the relation between households' Internet adoption and individual happiness without measuring the intensity of Internet use. In the latter case, the estimated welfare effect of the Internet can be biased by the fact that some individuals can use the Internet without being connected at home.

The objective of this article is to empirically examine how Internet use affects life satisfaction. We investigate this question at the individual level using Luxemburgish data from the 2008 European Social Survey. We find evidence that non-users are less satisfied in their life than Internet users. This result holds when we control for socio-demographic characteristics, social capital, values and beliefs. However, the relation between Internet use and well-being is weaker when we address endogeneity issues. Interestingly, the positive influence of Internet use is stronger for individuals who are young or not satisfied with their income.

Our research has theoretical and policy implications. First, our paper is related to the literature on happiness. This literature aims to explain why some countries are happier than other countries or what make people more satisfied with life. Research on happiness has made progress in identifying the determinants of happiness (Blanchflower and Oswald, 2004a,b; Dolan, Peasgood and Whife, 2008; Easterlin, 2001; Helliwell, 2006; Ferrer-i Carbonell and Frijters, 2004; Frey and Stutzer, 2002, 2010; Fritjers, Johnson and Shields, 2011; Oswald, 
1997). The main predictors of happiness are health, employment status, marital status, social capital, income and education. In other words, poor health, separation, unemployment and lack of social contact are strongly associated with low well-being. Our paper suggests that Internet use is likely to be a determinant of well-being that has yet not received a lot of attention in the happiness literature. Therefore, it opens a research stream on relationship between Internet type of usages and subjective well-being.

Our paper is also related to the literature on the digital divide (Di Maggio et alii, 2004; Goldfarb and Prince, 2008; Prieger and Hu, 2008; Drouard, 2011). Our research question is critical because if Internet use is positively correlated with happiness, then the digital divide may increase inequalities in well-being. Promoting or generalizing Internet usage in all population groups could be an effective policy to reduce social and economic disparities and equalize well-being.

The remainder of the paper is as follows. The next section describes data and the methodology. Section 3 presents the estimation results. The last section concludes.

\section{DATA AND METHODOLOGY}

\section{Description of the data}

We use the Luxemburgish part of the "European Value Survey" (EVS) to examine the relationship between happiness and Internet use. The EVS aims to provide insights into the ideas, beliefs, preferences, attitudes, values, and opinions of European citizens. We were allowed to add some questions about Internet use (intensity of Internet use, motives and individual benefits of the Internet) to the Luxemburgish survey. Unfortunately, it was not possible to replicate these questions in the EVS of other European countries. Nonetheless, the 
focus on Luxemburg is interesting for our research question because Luxemburg is a small European country with a highly heterogeneous population in terms of values, culture and social capital: $40 \%$ of the population is immigrant (see Sarracino (2011) for a detailed analysis of the relationship between social capital and well-being in Luxemburg).

The Luxemburgish EVS was conducted in face-to-face interviews from June to December, 2008. ${ }^{7}$ The eligible respondents were individuals who reside in Luxemburg and are at least 18-years-old. A stratified sample was extracted from the registration file of Social Security. 1,610 valid interviews were obtained, but only 1,332 questionnaires were complete for the purpose of our study. ${ }^{8}$ Table 1 presents the summary statistics for the variables used in our econometric analyses. The mean age of our respondents is 42.7 (the minimum age is 19 and the maximum age is 89) and the sample is equally distributed between male and female. Most of them $(64.0 \%)$ are married or live with a partner. $33.9 \%$ of the respondents have a pre-high school level, $36.2 \%$ a High school level, $14.3 \%$ a Bachelor degree and $15.6 \%$ more than a bachelor degree. $54.1 \%$ have a full time salaried job (at least 30 hours a week) or are selfemployed and $10.4 \%$ are part-time employee or unemployed. ${ }^{9}$

\section{[INSERT TABLE 1]}

Regarding the Internet part of the survey, $77.5 \%$ have used the Internet over the last three months at the time of the survey (in 2008). $75.9 \%$ have been using the Internet for more than

\footnotetext{
${ }^{7}$ Multiple languages were used to conduct the survey interviews: Luxemburgish, French, German, Portuguese, English. The 120 interviewers received specific training for this survey. The duration of interviews was between 2 and 3 hours.

${ }^{8}$ To improve the representativeness of the 1610 respondents, a sample-balancing step was performed. The weighting procedure uses additional information about gender, age and professional status in the Luxemburgish population.

9 The remaining respondents $(35.5 \%)$ are those who are not active on the labor market (student, retired, housewife, ...).
} 
4 years. On average, $38 \%$ of the respondents declared to be online several times per day, $22.3 \%$ once a day and $17.1 \%$ at least once a month (but not every day) ${ }^{10}$.

Now, we present the dependent and independent variables used in our econometric study.

\section{Dependent variables}

The European Value Survey provides two measures of subjective well-being. First, individuals are asked whether in general they feel satisfied with their life or not. They have to answer from 1 (very dissatisfied) to 10 (very satisfied). Figure 1 shows that the distribution of the responses is highly concentrated in the top of the scale (values of 8,9 and 10) with an average value of 7.8. This indicates that Luxemburgish people feel rather satisfied with their life. Individuals were also surveyed about how happy they are. $37.5 \%$ of them feel very happy, $57 \%$ quite happy and only $5.5 \%$ are not very happy or not at all happy. ${ }^{11}$

We prefer to choose life satisfaction (with its ten-point scale) as the dependent variable in our regressions because it enables us to run ordered logit as well as linear regression even if the ordinal nature of the variable is better taken into account with discrete choice models ${ }^{12}$.

\footnotetext{
${ }^{10} 56 \%$ of the Internet users have purchased or ordered goods and services over the last three months. $54.9 \%$ of them used an instant message system, and $50.5 \%$ used social networking services.

${ }^{11}$ In the literature on subjective well-being, it is sometimes argued that life satisfaction is a long term measure of well-being, whereas happiness is a short term measure.

12 However, we also conduct similar regressions with happiness as dependent variable to test the robustness of our results. Happiness is measured on a three-point scale : 1 when the individuals are not very happy or not at all happy, 2 when they are quite happy, and 3 when they are very happy
} 


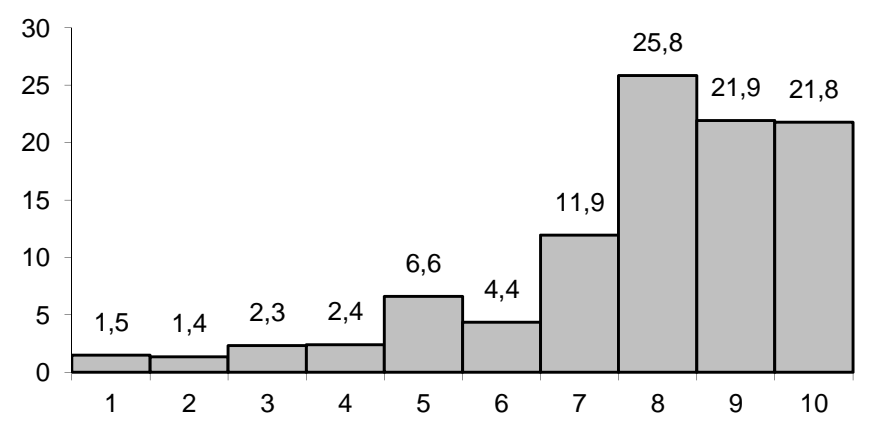

\section{Independent variables}

The intensity of Internet use is the variable of main interest. It is measured by four dummies: Onlineday+ if the Internet is used several times per day (38\%), OnlineDay if it is used only once per day (22.3\%), OnlineMonth if it is seldom connected (17.1\%), and NoInternet if the individual never uses the Internet $(22.6 \%)$. We think that the frequency of Internet use is a good measure of individual's exposure to the Internet. In particular, it would probably capture in a better way the "intent-to-use". With these four levels of frequency, we can test whether the well-being effects (if they exist) are uniform for all Internet users or depend on the intensity of exposure to the Internet.

We also introduce socio-demographic variables: gender, age (and age squared to control for non-linear effects of age on subjective well-being), marital status (living with a partner), education (primary, secondary, tertiary level) and occupational status (full-time job, part-time job/unemployed). Previous works have found a U-shaped curve between well-being and age: happiness tends to decrease until it reaches a minimum level around 40 years, and then increases with age (Blanchflower and Oslwald, 2004a). Regarding gender, women seem to report higher happiness, but this result is not very robust (Alesina et al. 2004). Being single 
(especially if recently separated or divorced) should decrease happiness (Helliwell, 2003). Having a part time job or being unemployed tend to be negatively correlated with well-being (Frey and Stutzer, 2002, Helliwell, 2003, Clark and Oswald, 1994). Finally, the effect of education is not clear and not significant in most empirical studies when controlling for health and income (Blanchflower et al. 2004a).

A second set of variables concerns sociability. We first create a membership score to measure the participation in voluntary organizations. We add one unit to the membership score when the individual belongs to at least one association in each of the following categories (i) Trade unions, ii) Sporting clubs, iii) Youth clubs iv) Religious or church organizations, v) Associations for educational or cultural activities, vi) Political parties or groups, vii) Associations for local community actions (job, housing, etc.), viii) Charities ix) Association for Third world development or human rights, x) Association for Conservation, ecology or animal rights, xi) Association for women rights xii) Professional associations, xiii) Peace movement, xiv) Organizations concerned with health, xv) Association for foreigners). A similar method is used to calculate a volunteer score, based on the number of organization in which the individual volunteers. On average, each individual belongs to 2.3 voluntary organizations and volunteers in 1.6 associations. We also calculate a sociability score based on the intensity of social interaction (or communication) with friends, workmates (out of office hours), members of the same church, and people belonging to the same associations ${ }^{13}$. The score of sociability is equal to 5.4 on average. Based on previous studies, we can expect a positive relationship between well-being and community involvement (membership or volunteering) (Pichler 2006, Helliwell 2003). Sociability (i.e. contacts with family and

\footnotetext{
${ }^{13}$ The sociability score is calculated by adding 3 points if the individual has regular meetings with his/her friends every week, 2 points if these meetings are only once or two times a month and 1 point if it is only few times per year (and zero otherwise). We do the same thing for the three other social groups. Hence, the highest possible value for the sociability score is 12 .
} 
friends) should also be positively correlated with happiness (Becchetti, Pelloni and Rossetti, 2008).

A third set of variables concerns values and attitudes. We control for trust in the other and in the institutions. Trust in the other is based on the following question: "do you think that most people would try to take advantage of you if they got the chance, or would they try to be fair?" People must choose on a 10-point scale from 1 (Most people would try to take advantage of me) to 10 (Most people would try to be fair). Trust in the institution is a score that measures the confidence in eight institutions: press, trade unions, police, parliament, government, justice, political parties and public or civil services. For each institution, the score takes the value 0 if the individual has no or little confidence, 1 for a certain level of confidence and 2 for a strong confidence. The score reaches its maximum at 16, but on average is equal to 5.6.

We also introduce a binary variable that equals 1 if the individual believes in god. We also take into account the feeling of freedom and control. People were asked how much freedom of choice and control they have over the way their life turns out (on a 10 point scale with 1 for no control to 10 for a great deal of control). This variable allows us to distinguish people who attribute the outcome of their actions to internal factors such as skills and efforts and those who tend to attribute it to external factors like fate and destiny. We have also a measure of ideological preferences on income distribution. People were asked whether they agree that incomes should be more equal or there should be greater incentives for individual effort (a scale from 1 to 10). We expect belief in God and church attendance to have a positive effect on life satisfaction (Helliwell 2003). Stronger religious beliefs may give people more confidence in their future and act as a buffer against stress and life accident (Clark and Lelkes, 2005). Moreover, social trust has substantial positive effects on well-being and is associated with a lower probability of suicide (Helliwell and Putnam, 2004, Bjornskov, 2003). Political 
perceptions can also matter for happiness. Conservatives tend to be happier than liberals because the latter are very sensitive to inequality. They feel unsatisfied or frustrated by the existing social and political system and would prefer less income disparity whereas conservatives are satisfied with status quo (Napier and Jost, 2008). Finally, people who believe that they have a greater control or freedom over their choices are happier (Verme, 2009).

Finally, we introduce a subjective measure for health and income satisfaction with a seven point scale (1 for very unsatisfied to 7 for very satisfied). The majority of the population declares a high level of health and income satisfaction (5.5 for health satisfaction and 5 for income satisfaction on average). Obviously, income and health satisfaction should increase the overall life satisfaction as both are among the main factors influencing well-being (Frey and Stutzer, 2002). Moreover, many studies consistently show a strong relationship between life satisfaction and both physical and psychological (or mental) health.

To sum up, our life satisfaction (LS) model can be represented as follows:

$$
L S_{i}=\beta_{0}+\beta_{1} \text { InternetUse }+\beta_{2} \text { Sociodemographics }+\beta_{3} \text { Sociability }+\beta_{4} \text { Values }+\beta_{5} \text { Income }+\beta_{6} \text { Health }+\varepsilon_{i}
$$

Since the dependent variable is ordinal, we estimate the determinants of life satisfaction with ordered logit models. We also conduct OLS regressions: the results are qualitatively similar to those obtained with ordered logit models, but are more questionable given the ordinal nature of our dependent variable (see table 4 in appendix).

\section{RESULTS AND ROBUSTNESS CHECKS}




\section{Determinants of Life satisfaction}

Table 2 reports the results of the ordered logit regressions. The first column is the baseline regression including the intensity of Internet use and the socio-demographic characteristics as explanatory variables. We find a significant negative relation between the non-use of the Internet and life satisfaction. However, among the Internet users, there is no significant difference between the heavy and light users. This suggests that being deprived of Internet access (i.e. being on the wrong side of the digital divide) has a detrimental effect on the wellbeing. As expected, living with a partner increases life satisfaction whereas having a part time job or being unemployed has the opposite effect. Life satisfaction also decreases with age, but at a decreasing rate. Finally, education and gender have no effect.

\section{[INSERT TABLE 2]}

In column 2, we introduce the variables related to social capital (sociability and community involvement). Belonging to voluntary organizations and volunteering have no impact on wellbeing. But, having frequent contacts with friends or acquaintances increases life satisfaction. In column 3, we add the set of explanatory variables related to individual values and beliefs. People who trust the other or the institutions more, and thus have more control on their life, feel more satisfied. These findings are consistent with previous studies (Verme, 2009, Helliwell, 2003). Moreover, individuals who have strong preferences for equal income are less likely to be satisfied with their life, as was shown in Napier and Jost (2008). Finally, belief in god does not affect life satisfaction. 
Column 4 introduces two additional factors that we suspect to be strong predictors of wellbeing: the level of satisfaction regarding health and income ${ }^{14}$. They have the expected positive sign and are highly significant. Individuals who declare to be healthy and be comfortable with their income are also very satisfied with their life. When we control for income and health satisfaction, it reduces the negative impact of no Internet use on life satisfaction. However, this decrease does not nullify the impact, which still remains significant. This confirms our intuition that the digital divide affects life satisfaction. Interestingly, the level of education becomes significant when we take into account the level of income. People with the highest degree of education (Master/phD) tend to declare lower level of well-being after controlling for income and health satisfaction.

It is often argued that Internet use could lead to different returns depending on the skills and characteristics of the users. To test this idea, we introduce interaction variables between the intensity of Internet use and the following variables (age, partner, gender, sociability and income). First, we find a negative estimated coefficient for ONLINE*AGE, meaning that the positive impact of Internet use on life satisfaction is stronger for the youngest generations (called the digital natives) and decreases with age. Similarly, ONLINE*INCOME has a negative and significant coefficient. People that are less satisfied with their income seem to get higher returns from using the Internet. Such a result is a strong argument to promote Internet access in low-income population. Moreover, when we introduce the interaction variables, it appears that using the Internet intensively (several times every day) becomes a significant source of satisfaction. This finding implies that any public policy that encourages people to spend more time online could also be welfare-enhancing.

\footnotetext{
${ }^{14}$ Relationship between well-being and income is not always linear even if basically, both variable are positively correlated (Easterlin, 2001).
} 
We run similar regressions using Happiness as the dependent variable. The results are presented in Table 5 (in appendix). We find that Internet non-adopters tend to be less happy that the Internet users (whatever their frequency of Internet use), but this impact is weakly significant (at $10 \%$ when we only control for socio-demographic variables). In the literature on subjective well-being, it is sometimes argued that life satisfaction is a long term measure of well-being, whereas happiness is a short term measure. Following this interpretation, our findings suggest that Internet use has more long term than short term effects. For the other explanatory variables, the effects are comparable to what we have found for life satisfaction. Individuals that are young and healthy, live with a partner and have a comfortable income are happier. Similarly, happiness is positively related to trust and freedom, but negatively related to fairness.

\section{Robustness Checks}

It may be argued that the significant effect of Internet use on well-being is flawed due to some endogeneity problems. It is possible that omitted variables in the estimated models influence both the intensity of Internet use and well-being, or that people who are more satisfied with their life are more likely to use the Internet (inverse causality). For these reasons, we use an instrumental variables 2SLS approach to control for the endogeneity of Internet use. Our instrument is the diffusion of the Internet among family (whether most or few family members use the Internet). ${ }^{15} \mathrm{We}$ have reasons to believe that this variable is strongly correlated with the frequency of Internet use. Agarwal, Animesh and Prasad (2009) find that widespread Internet use among people who live in proximity (neighbors, friends, relatives, ...) has a direct effect on an individual's propensity to go online (see also Goolsbee and

\footnotetext{
${ }^{15}$ A good instrument must satisfy two conditions: 1) a relevance condition (the instrumental variable must be statistically correlated to the potentially endogeneous variable) and an orthogonality condition (the instrument must be uncorrelated with the error term of the life satisfaction equation).
} 
Zittrain, 1999). Similarly, Goldfarb (2006) provide evidence of important local spillover in Internet adoption, especially within households. However, the diffusion of the Internet among relatives is largely determined by the presence of early adopters or technology-savvy person within one's family and this is exogenous to individual's life satisfaction.

In the first stage of the Instrumental Variable model, the dependent variable is the intensity of Internet measured by a four-point scale ( 1 if no Internet use, 2 if Internet use at least once a month, 3 if once a day and 4 if several times a day). This variable is regressed on gender, age, occupational status, education, sociability, membership and volunteer and the instrumental variable (Internet diffusion among relatives). To check the validity of our instrument, we perform several tests. The first-stage F-statistics (to test the relevance of our excluded instruments) are largely above 10 that is considered as the rule of thumb threshold above which we can ignore the weak instrument problem. Moreover, the coefficient associated to the instrument variable in the first stage regression is highly significant $(\mathrm{p}<.001)$. We can conclude that our instrument satisfies the conditions for valid IV, i.e., correlated with Internet use and uncorrelated with life satisfaction ${ }^{16}$. Moreover, the $\mathrm{Wu}$-Hausman test indicates that the consistency of OLS cannot be rejected and suggests that the endogeneity of Internet use is not a serious problem.

Table 3 presents the results of the second stage. Internet use has a significant positive impact on well-being when we control for socio-demographic characteristics, sociability and values. However, when we take into account the level of health and income satisfaction, the intensity of Internet use is no more significant. This result suggests that the relationship between Internet use and life satisfaction is not clear-cut. A possible explanation might be that Internet

$16 \mathrm{We}$ also run a regression of our instrument (FamilyInternet) on the happiness covariates. If these variables have a limited marginal effect on FamilyInternet, it means that most of the variation for this instrument is unrelated to happiness covariates. Table 6 in appendix shows that most variables are not correlated with the probability to have a lot of Internet users among family member. 
use has positive effects on income satisfaction insofar as the Internet helps people find good deals (online shopping), free entertainment (music, video, information) or better paid jobs. In this case, the well-being effect of Internet use is mediated through income satisfaction (and to a less extent through health satisfaction). However, additional data are required to test this idea and provide more robust measures of the well-being effects of Internet use.

\section{[INSERT TABLE 3]}

\section{CONCLUSION}

The goal of this article is to investigate the links between Internet use, social capital and happiness. We have focused our analysis on a specific country (Luxemburg) and used the EVS data to which we had the opportunity to add questions on the frequency of Internet use. This unique set of data allows us to examine more rigorously the relation between Internet use and subjective well-being. Our findings indicate that the first level of the digital divide (whether people use the Internet or not) generates more inequality in life satisfaction than the second level of the digital divide (between light and heavy Internet users). Moreover, Internet use is more influential on life satisfaction than on happiness, suggesting that digital use has long-term effects. Finally, we find that the benefits of using the Internet are higher for the younger generations and the individuals who are not satisfied with their income. These findings have clear implications. Policy that promotes digital literacy at school and in low income populations has to be encouraged and could maximize well-being in society as a whole.

Our research has several limitations. Our data are cross-sectional and limited to one European country (Luxemburg). Further analyses have to be developed using more appropriate data (time-series and cross-country data) to have more robust measures of the short-term and long- 
term effects of Internet use on well-being. It would also be interesting to understand which kinds of online use have positive or negative effects on life satisfaction (communication, information search, online games, social network site, etc...). But, this paper is a first stone in this promising avenue to understand the interplay between digital use (Internet, Mobile Phone, Tablet, Smart TV, etc...) and well-being.

\section{REFERENCES}

Agarwal, R., Animesh A., and Prasad, K. (2009) "Social Interactions and the Digital Divide: Explaining Regional Variations in Internet Use”, Information System Research, 277-294.

Alesina, A., Di Tella, R., and McCulloch, R., (2004) "Inequality and happiness: Are Europeans and Americans different?" Journal of Public Economics 88, 2009-2042.

BCS, The Chartered Institute for IT by Trajectory Partnership, (2010) "The Information Dividend: Why IT makes you 'happier'," http://www.bcs.org/upload/pdf/info-dividend-full-report.pdf, Accessed 21st Dec 2010.

Becchetti, L., Pelloni, A., and Rossetti, F., (2008) "Relation Goods, Sociability, and Happiness," Kyklos, 61(3), 343-363.

Bellou, A. (2013) "The Impact of Internet Diffusion on Marriage Rates: Evidence from the Broadbrand Market”, Working Paper http://ftp.iza.org/dp7316.pdf

Bjornskov, C. (2003) "The happy few: cross country evidence on social capital and life satisfaction." Kyklos 56(1), 3-16.

Blanchflower, D.G., and Oswald, A.J. (2004a) "Well-being over time in Britain and the USA" Journal of Public Economics, 88 (7-8), 1359-1386.

Blanchflower, D. G. and Oswald, A. J. (2004b), "Money, Sex and Happiness: An Empirical Study," The Scandinavian Journal of Economics, 106: 393-415.

Bruni, L., and Stanca, L., (2008) "Watching alone: Relational goods, television and happiness," Journal of Economic Behavior \& Organization, 65(3-4), 506-528. 
Bruni, L., and Stanca, L., (2006) "Income Aspirations, Television and Happiness: Evidence from the World Values Survey" Kyklos, 59(2), 209-225.

Castronova, E and Wagner, G. (2011) “Virtual Life Satisfaction”, Kyklos, 64(3), 313-328.

Chan J., Chose A., (2012) "Internet's dirty secret: assessing the impact of online intermediaries on HIV transmission", Working paper NYU Stern, http://papers.ssrn.com/sol3/papers.cfm?abstract_id=2035585

Clark A., and Lelkes, O., (2005), "Deliver us from evil: religion as insurance”, Working Paper Paris School of Economics.

Clark, A., and Oswald, A.J. (1994). "Unhappiness and Unemployment", The Economic Journal, 104(424), 648-659.

DiMaggio, P., Hargittai E., Celeste, C., and Shafer, S. (2004) "From Unequal Access to Differentiated Use: A Literature Review and Agenda for Research on Digital Inequality", in: Neckerman K (Eds), Social Inequality. New York: Russell Sage Foundation.

Dolan, P., Peasgood, T., and White, M. (2008). "Do we really know what makes us happy? A review of the economic literature on the factors associated with subjective well-being." Journal of Economic Psychology, 29, 94-122.

Drouard, J. (2011) "Costs or gross benefits? What mainly drives cross-sectional variance in Internet adoption," Information Economics and Policy 23, 127-140.

Easterlin, R.A., (2001) "Income and happiness: towards a unified theory," The Economic Journal 111, 465-484.

Ellison N., Steinfield C., and Lampe, C., (2007), "The benefits of facebook "friends":social capital and college students' use if online social network sites", Journal of Computer Mediated Communication, 12, 1143-1168.

Ferrer-i Carbonell, A., and Frijters, P. (2004). "How important is methodology for the estimates of the determinants of happiness?" The Economic Journal, 114, 641-659.

Ford G. and S. G. Ford (2009) "Internet Use and Depression among the Elderly", Phoenix Center Policy Paper Number 38.

Franzen, A. (2003) "Social Capital and the Internet: Evidence from Swiss Panel Data", Kyklos 56(3), 341-360.

Frey, B., and Stutzer, A. (2002). "What can economists learn from happiness research?" Journal of Economic Literature, 40 (2), 402-435. *

Frey, B., and Stutzer, A. (2010) "Happiness and Public Choice", Public Choice 144, 557-573.

Frey, B., Benesch, C., and Stutzer, A. (2007). "Does watching TV make us happy?” Journal of Economic Psychology, 28 (3), 283-313. 
Frijters, P., Johnston, D. W. and Shields, M. A. (2011), "Life Satisfaction Dynamics with Quarterly Life Event Data,” The Scandinavian Journal of Economics, 113: 190-211.

Glaeser, E.L., Laibson D., and Sacerdote, B. (2002) "An Economic Approach to Social Capital", Economic Journal 112, 437-58.

Goldfarb, A, and Prince, J.T. (2008) "Internet Adoption and Usage Patterns are Different: Implications for the Digital Divide”, Information Economics and Policy 20, 1, 2-15.

Goldfarb, A. (2006) "The (Teaching) Role of Universities in the Diffusion of the Internet", International Journal of Industrial Organization 24 (2), 203-225.

Goolsbee A. and P. Klenow (2006) "Valuing Consumer Products by the Time Spent Using them: an Application to the Internet", American Economic Review, Papers and Proceedings, 96 (2), 108-113.

Goolsbee, A., and Zittrain, J. (1999). "Evaluating the Costs and Benefits of Taxing Internet Commerce", National Tax Journal, 413-428.

Gordon, R. J. (2003) "Exploding Productivity Growth: Context, Causes, and Implications." Brookings Papers on Economic Activity, 2, 207-79.

Gui B., and Stanca, L., (2010), "Happiness and relational goods: well-being and interpersonal relations in the economic sphere", International Review of Economics, 57, 105-118.

Helliwell J.F. and H. Huang (2013) "Comparing the Happiness Effects of real and online friends", Working Paper NBER 18690.

Helliwell J.F. (2006) “Well-Being, Social capital and Public policy: What's new?" The economic Journal 116, 34-45.

Helliwell, J. F., and Putnam, R. (2004). “The social context of well-being”, Philosophical Transactions of the Royal Society London, 359, 1435-1446.

Helliwell, J.F. (2003) "How's life? Combining individual and national variables to explain subjective well-being." Economic Modeling, 20, 331-360.

Hong, S. (2007), "The recent growth of the internet and changes in household-level demand for entertainment", Information Economics and Policy, 19 (3-4), 304-318.

Kavetsos G. and Koutroumpis, P. (2011) "Technological Affluence and Subjective WellBeing”, Journal of Economic Psychology 32, 742-753

Kraut, R., Kiesler, S., Boneva B., Cummings, J., Helgeson V, and Crawford, A. (2002) “Internet Paradox Revisited.” Journal of Social Issues 58, 49-74.

Lee P., Leung, L., Lo V., Xiong C. and T. Wu (2011) "Internet Communication Versus Faceto-Face in Quality of Life", Social Indicators Research 100, 375-389. 
Li, S.-M. and Chung, T.-M. (2006), "Internet function and Internet addictive behavior", Computers in Human Behavior, 22 (6), 1067-1071.

Napier J. and Jost, J. (2008) "Why are Conservatives Happier than Liberals?" Psychological Science, 19 (6), 565-572.

Nie, N. H, Hillygus, S. D. and Erbring, L. (2002) "Internet Use, Interpersonal Relations, and Sociability in The Internet" in: B. Wellman and C. Haythornthwaite (eds). Everyday Life. Oxford: Blackwell,.

Oswald, A.J. (1997) "Happiness and economic performance." Economic Journal, 107 (445), $1815-31$.

Pénard, T. and Poussing, N. (2010) "Internet Use and Social Capital: The Strength of Virtual Ties", Journal of Economic Issues, 44 (3), 569-595.

Pope, Devin and Kory Kroft (2012) "Does Online Search Crowd Out Traditional Search and Improve Matching Efficiency? Evidence from Craigslist”, Journal of Labor Economics, forthcoming.

Pichler, F. (2006) 'Subjective quality of life of young Europeans. Feeling happy but who knows why?" Social Indicators Research, 75, 419-444. Prieger, J.E., and Hu, W-M., (2008) "The broadband digital divide and the nexus of race, competition, and quality", Information Economics and Policy 20 (2), 150-167.

Putnam, R. (2000) Bowling alone: The Collapse and Revival of American Community, New York. Simon and Schuster.

Sabatini F. (2011) "Can a click buy a little happiness? The impact of business-to-consumer ecommerce on subjective well-being", WPcomunite, Department of Communication, University of Teramo.

Sarracino, F. (2011) "Richer in money, poorer in relationship and unhappy? Time series comparisons of social capital and well-being in Luxembourg," CEPS/INSTEAD Working Paper Series 2011-01.

Shklovski, I., Kiesler, S. and Kraut, R. (2006) "The Internet and Social Interaction: A Metaanalysis and Critique of Studies, 1995-2003”, in: Kraut, Robert, Brynin, M., and Sara Kiesler (eds), Computers, Phones, and the Internet: The Social Impact of Information Technology. Oxford University Press.

Steinfield, C., Ellison, N.B. and Lampe, C. (2008) "Social capital, self-esteem and use of online social network sites: A longitudinal analysis", Journal of Applied Developmental Psychology, 29 (6), 434-445. 
Uhlaner C. J. (1989) "Relational goods and participation: Incorporating sociability into a theory of rational action," Public Choice, 62:253-285.

Verme P. (2009) "Happiness, freedom and Control", Journal of economic Behavior \& Organization, 71, 146-161. 
Table 1: Description and summary statistics of the variables

\begin{tabular}{|c|c|c|}
\hline Variable & Description & $\begin{array}{c}\text { Mean } \\
\text { (Standard error) }\end{array}$ \\
\hline HAPPINESS & $\begin{array}{l}\text { All things consider would you say that you are: not very happy/not at all happy }(=1) \text {, quite } \\
\text { happy }(=2) \text {, very happy }(=3)\end{array}$ & $\begin{array}{c}2.251 \\
(0.748) \\
\end{array}$ \\
\hline LIFE SATISFACTION & $\begin{array}{l}\text { All things considered, how satisfied are you with your life as a whole these days? Values } \\
\text { from } 1 \text { (dissatisfied) to } 10 \text { (satisfied). }\end{array}$ & $\begin{array}{c}7.851 \\
(2.036)\end{array}$ \\
\hline ONLINEDAY+ & Use the Internet several times per day & $\begin{array}{c}0.380 \\
(0.485)\end{array}$ \\
\hline ONLINEDAY & Use the Internet once a day & $\begin{array}{c}0.223 \\
(0.416) \\
\end{array}$ \\
\hline ONLINEMONTH & Use the Internet at least once a month (but not every day) & $\begin{array}{c}0.171 \\
(0.376)\end{array}$ \\
\hline NOINTERNET & Has never used the Internet over the past 3 months & $\begin{array}{c}0.226 \\
(0.418)\end{array}$ \\
\hline ONLINEINTENSE & $\begin{array}{l}\text { Intensity of Internet use; Take value } 1 \text { if No Internet use, } 2 \text { if Internet use at least once a } \\
\text { month, } 3 \text { if one a day and } 4 \text { if several times a day }\end{array}$ & $\begin{array}{l}2.486 \\
(1.567)\end{array}$ \\
\hline AGE & Age of the respondent (from 19 to 89 ) & $\begin{array}{c}42.693 \\
(17.107)\end{array}$ \\
\hline AGE2 & Age squared & $\begin{array}{c}2115.184 \\
(1643.369) \\
\end{array}$ \\
\hline PARTNER & Married or with a partner & $\begin{array}{c}0.640 \\
(0.480)\end{array}$ \\
\hline GENDER & Male & $\begin{array}{c}0.506 \\
(0.500)\end{array}$ \\
\hline PRIMARY EDUCATION & Primary or first stage of basic education & $\begin{array}{c}0.339 \\
(0.473) \\
\end{array}$ \\
\hline SECONDARY EDUCATION & Upper secondary education (High school level) & $\begin{array}{c}0.361 \\
(0.480)\end{array}$ \\
\hline $\begin{array}{l}\text { TERTIARY EDUCATION } \\
\text { STAGE } 1\end{array}$ & The first stage of Tertiary education (University License or Bachelor) & $\begin{array}{c}0.144 \\
(0.349)\end{array}$ \\
\hline $\begin{array}{l}\text { TERTIARY EDUCATION } \\
\text { STAGE } 2\end{array}$ & The second stage of Tertiary education (Master, Doctorate) & $\begin{array}{c}0.156 \\
(0.363)\end{array}$ \\
\hline FULLTIMEJOB & Has a full time salaried job (at least 30 hours a week) or is self employed & $\begin{array}{c}0.541 \\
(0.498)\end{array}$ \\
\hline PARTTIMEJOB & Has a part time salaried job (less than 30 hours a week) or is unemployed & $\begin{array}{c}0.104 \\
(0.305) \\
\end{array}$ \\
\hline NOACTIVITY & $\begin{array}{l}\text { Has no professional activity (Retired/pensioned, Housewife not otherwise employed, } \\
\text { Student, Disabled) }\end{array}$ & $\begin{array}{c}0.355 \\
(0.486) \\
\end{array}$ \\
\hline MEMBERSHIP & Membership in voluntary organisations (number) & $\begin{array}{c}2.316 \\
(1.880)\end{array}$ \\
\hline VOLUNTEER & Volunteer in organisations (number) & $\begin{array}{c}1.593 \\
(1.932)\end{array}$ \\
\hline SOCIABILITY & $\begin{array}{l}\text { Intensity of meeting with friends, fellow workers, people attending the same church, clubs } \\
\text { and associations }\end{array}$ & $\begin{array}{c}5.436 \\
(2.369) \\
\end{array}$ \\
\hline TRUSTOTHER & $\begin{array}{l}\text { Trust in others (do you think that most people would try to take advantage of you if they } \\
\text { got the chance, or would they try to be fair? Takes value from } 1 \text { (Most people would try to } \\
\text { take advantage of me) to } 10 \text { (Most people would try to be fair) }\end{array}$ & $\begin{array}{c}6.072 \\
(2.263)\end{array}$ \\
\hline GOD & Believes in God & $\begin{array}{c}0.620 \\
(0.485)\end{array}$ \\
\hline FREEDOM & $\begin{array}{l}\text { Freedom of choice and control you feel you have over the way your life turns out. Some } \\
\text { people feel they have completely free choice and control over their lives, and other people } \\
\text { feel that what they do has no real effect on what happens to them. Takes value from } 1 \text { (no } \\
\text { freedom of choice) to } 10 \text { (a great deal of freedom). }\end{array}$ & $\begin{array}{c}6.840 \\
(2.301)\end{array}$ \\
\hline FAIRNESS & $\begin{array}{l}\text { Preference for equal incomes. Takes value } 1 \text { (There should be greater incentives for } \\
\text { individual effort) to } 10 \text { (Incomes should be made more equal) }\end{array}$ & $\begin{array}{c}4.636 \\
(2.658)\end{array}$ \\
\hline TRUSTINSTITUTION & $\begin{array}{l}\text { Measure of confidence in institutions (press, trade union, police, parliament, government, } \\
\text { justice, political parties, civil service). }\end{array}$ & $\begin{array}{c}5.626 \\
(3.350)\end{array}$ \\
\hline HEALTH & $\begin{array}{l}\text { Satisfaction level regarding health (are you satisfied with your health?). Takes value from } 1 \\
\text { (Very unsatisfied) to } 7 \text { (Very satisfied). }\end{array}$ & $\begin{array}{c}5.563 \\
(1.532) \\
\end{array}$ \\
\hline INCOME & $\begin{array}{l}\text { Satisfaction level regarding income (are you satisfied with your income?). Takes value } \\
\text { from } 1 \text { (Very unsatisfied) to } 7 \text { (Very satisfied). }\end{array}$ & $\begin{array}{c}5.068 \\
(1.725) \\
\end{array}$ \\
\hline ONLINE*AGE & Interaction between ONLINEINTENSE and AGE & $\begin{array}{c}66.707 \\
(53.767) \\
\end{array}$ \\
\hline ONLINE*PARTNER & Interaction between ONLINEINTENSE and PARTNER & $\begin{array}{c}1.055 \\
(1.250)\end{array}$ \\
\hline ONLINE*GENDER & Interaction between ONLINEINTENSE and GENDER & $\begin{array}{c}0.946 \\
(1.276)\end{array}$ \\
\hline ONLINE*SOCIABILITY & Interaction between ONLINEINTENSE and SOCIABILITY & $\begin{array}{l}10.328 \\
(8.528)\end{array}$ \\
\hline ONLINE*INCOME & Interaction between ONLINEINTENSE and INCOME & $\begin{array}{c}8.948 \\
(7.007)\end{array}$ \\
\hline FAMILYINTERNET & Most of family members use the Internet & $\begin{array}{c}0.843 \\
(0.363)\end{array}$ \\
\hline
\end{tabular}


Table 2: The determinants of life satisfaction (ordered logit model)

\begin{tabular}{|c|c|c|c|c|c|}
\hline \multicolumn{6}{|c|}{ Dependant variable: LIFE SATISFACTION } \\
\hline & 1 & 2 & 3 & 4 & 5 \\
\hline ONLINEDAY+ & $\begin{array}{c}-0.016148514 \\
(0.1505678056)\end{array}$ & $\begin{array}{c}-0.021138746 \\
(0.1510150244)\end{array}$ & $\begin{array}{c}-0.097167547 \\
(0.1528190781)\end{array}$ & $\begin{array}{c}-0.023534512 \\
(0.1535203528)\end{array}$ & $\begin{array}{c}1.2788455421 * * * * \\
(0.4236607752) \\
\end{array}$ \\
\hline ONLINEDAY & $\begin{array}{c}-0.170364147 \\
(0.1576495828)\end{array}$ & $\begin{array}{c}-0.202974905 \\
(0.1580004722)\end{array}$ & $\begin{array}{l}-0.216543144 \\
(0.159282883)\end{array}$ & $\begin{array}{c}-0.166001114 \\
(0.1600754436)\end{array}$ & $\begin{array}{l}0.4834739146^{*} \\
(0.2526624604)\end{array}$ \\
\hline ONLINEMONTH & REF. & REF. & REF. & REF. & REF. \\
\hline NOINTERNET & $\begin{array}{c}-0.527679854 * * * \\
(0.1722508055)\end{array}$ & $\begin{array}{l}-0.42446805^{* *} \\
(0.1734546903)\end{array}$ & $\begin{array}{c}-0.44255588 * * \\
(0.176309891)\end{array}$ & $\begin{array}{l}-0.318767221^{*} \\
(0.1774934962)\end{array}$ & $\begin{array}{c}-1.064734903 * * * \\
(0.2964199493)\end{array}$ \\
\hline AGE & $\begin{array}{c}-0.051748168 * * * \\
(0.0188493099)\end{array}$ & $\begin{array}{c}-0.055273586 * * * \\
(0.0189708842)\end{array}$ & $\begin{array}{c}-0.049084039 * * \\
(0.0192222694)\end{array}$ & $\begin{array}{c}-0.039542794 * * \\
(0.0193620368)\end{array}$ & $\begin{array}{c}-0.017509984 \\
(0.0228730541)\end{array}$ \\
\hline AGESQUARED & $\begin{array}{c}0.0007262488 * * * \\
(0.0002008996)\end{array}$ & $\begin{array}{c}0.0007634641 * * * \\
(0.0002018665)\end{array}$ & $\begin{array}{c}0.0006759522^{* * *} * \\
(0.0002049965)\end{array}$ & $\begin{array}{c}0.000556179 * * * \\
(0.0002058541)\end{array}$ & $\begin{array}{l}0.0004143269^{*} \\
(0.0002197725)\end{array}$ \\
\hline PARTNER & $\begin{array}{c}0.4563572395 * * * \\
(0.1132794538)\end{array}$ & $\begin{array}{c}0.5073516583 * * * \\
(0.1138830231)\end{array}$ & $\begin{array}{c}0.5035137274 * * * \\
(0.1154519423)\end{array}$ & $\begin{array}{c}0.3563798402 * * * \\
(0.1166782073)\end{array}$ & $\begin{array}{c}0.4659129638 * * \\
(0.2063270616)\end{array}$ \\
\hline GENDER & $\begin{array}{c}0.1142624925 \\
(0.1032711253)\end{array}$ & $\begin{array}{c}0.0607961395 \\
(0.1041685254)\end{array}$ & $\begin{array}{c}0.1026776996 \\
(0.1061467756)\end{array}$ & $\begin{array}{c}0.1060389657 \\
(0.1070246812)\end{array}$ & $\begin{array}{c}0.1744188339 \\
(0.1876317789)\end{array}$ \\
\hline PRIMARY EDUCATION & $\begin{array}{c}0.0173371341 \\
(0.1223076375)\end{array}$ & $\begin{array}{c}0.0597044492 \\
(0.1230410354)\end{array}$ & $\begin{array}{c}0.1125473409 \\
(0.1249421228)\end{array}$ & $\begin{array}{c}0.1539133811 \\
(0.1257281408)\end{array}$ & $\begin{array}{c}0.1597111174 \\
(0.1259386771)\end{array}$ \\
\hline $\begin{array}{l}\text { SECONDARY } \\
\text { EDUCATION }\end{array}$ & REF. & REF. & REF. & REF. & REF \\
\hline $\begin{array}{l}\text { TERTIARY } \\
\text { EDUCATION STAGE } 1\end{array}$ & $\begin{array}{c}0.1096346423 \\
(0.1561834284)\end{array}$ & $\begin{array}{c}0.0445005272 \\
(0.1568805954)\end{array}$ & $\begin{array}{c}0.053244968 \\
(0.1593018668)\end{array}$ & $\begin{array}{l}-0.018415911 \\
(0.160354303)\end{array}$ & $\begin{array}{c}-0.013182638 \\
(0.1608528024)\end{array}$ \\
\hline $\begin{array}{l}\text { TERTIARY } \\
\text { EDUCATION STAGE } 2\end{array}$ & $\begin{array}{c}-0.120479668 \\
(0.1586128503)\end{array}$ & $\begin{array}{c}-0.092377399 \\
(0.159045345)\end{array}$ & $\begin{array}{c}-0.213616178 \\
(0.1609418868)\end{array}$ & $\begin{array}{l}-0.333436703 * * \\
(0.1619930584)\end{array}$ & $\begin{array}{l}-0.308146056^{*} \\
(0.1622984796)\end{array}$ \\
\hline FULLTIMEJOB & $\begin{array}{c}0.0585709553 \\
(0.1311462015) \\
\end{array}$ & $\begin{array}{c}0.0500086346 \\
(0.1316907029)\end{array}$ & $\begin{array}{c}0.0538874119 \\
(0.1328095013)\end{array}$ & $\begin{array}{c}-0.085938238 \\
(0.1340891576)\end{array}$ & $\begin{array}{c}-0.076398081 \\
(0.1354543667)\end{array}$ \\
\hline PARTTIMEJOB & $\begin{array}{c}-0.516431515 * * * \\
(0.1846855767) \\
\end{array}$ & $\begin{array}{c}-0.526642892 * * * \\
(0.1848147871) \\
\end{array}$ & $\begin{array}{c}-0.43635178 * * \\
(0.1858460686)\end{array}$ & $\begin{array}{c}-0.467370435^{* * *} \\
(0.1869029551)\end{array}$ & $\begin{array}{l}-0.46368495 * * \\
(0.1873141083) \\
\end{array}$ \\
\hline NOACTIVITY & REF. & REF. & REF. & REF. & REF. \\
\hline MEMBERSHIP & & $\begin{array}{c}0.0433917045 \\
(0.0361188411) \\
\end{array}$ & $\begin{array}{c}0.0090215303 \\
(0.0365523028)\end{array}$ & $\begin{array}{c}0.0154950612 \\
(0.0367126455)\end{array}$ & $\begin{array}{c}0.0136530316 \\
(0.0367569416) \\
\end{array}$ \\
\hline VOLUNTEER & & $\begin{array}{c}0.0506543177 \\
(0.0369929108)\end{array}$ & $\begin{array}{c}0.0749784936^{* * *} \\
(0.0374858896)\end{array}$ & $\begin{array}{l}0.0667960216^{*} \\
(0.0376028824)\end{array}$ & $\begin{array}{l}0.0692250482^{*} \\
(0.0377809669)\end{array}$ \\
\hline SOCIABILITY & & $\begin{array}{c}0.0573451139 * * \\
(0.0233837869)\end{array}$ & $\begin{array}{l}0.0455044585^{*} \\
(0.0236162633)\end{array}$ & $\begin{array}{c}0.0338663834 \\
(0.02373833)\end{array}$ & $\begin{array}{c}0.0774022885 * * \\
(0.0392529099)\end{array}$ \\
\hline TRUSTOTHER & & & $\begin{array}{c}0.0952651927 * * * \\
(0.0232093833)\end{array}$ & $\begin{array}{c}0.0539200242 * * \\
(0.0235625417)\end{array}$ & $\begin{array}{c}0.0488605149 * * \\
(0.0237840381)\end{array}$ \\
\hline GOD & & & $\begin{array}{c}-0.063349334 \\
(0.1056646863)\end{array}$ & $\begin{array}{c}-0.05796692 \\
(0.1063962309)\end{array}$ & $\begin{array}{c}-0.065276767 \\
(0.1066263596)\end{array}$ \\
\hline FREEDOM & & & $\begin{array}{c}0.2918947619 \text { *** } \\
(0.0231051167)\end{array}$ & $\begin{array}{c}0.2553678496 * * * \\
(0.0232545971)\end{array}$ & $\begin{array}{c}0.2522961688 * * * * \\
(0.0232771219)\end{array}$ \\
\hline FAIRNESS & & & $\begin{array}{l}-0.04802511 * * \\
(0.0187276987) \\
\end{array}$ & $\begin{array}{c}-0.039664014^{* *} * \\
(0.0188603783) \\
\end{array}$ & $\begin{array}{c}-0.044862005^{* *} \\
(0.0190333649) \\
\end{array}$ \\
\hline TRUSTINSTITUTION & & & $\begin{array}{c}0.0529887491 * * * \\
(0.0153238559)\end{array}$ & $\begin{array}{c}0.0459392336^{* * * *} \\
(0.0154451401)\end{array}$ & $\begin{array}{c}0.0486512728 * * * * \\
(0.0155227181)\end{array}$ \\
\hline HEALTH & & & & $\begin{array}{c}0.3400756807 * * * \\
(0.0365612954) \\
\end{array}$ & $\begin{array}{c}0.3409300835 * * * * \\
(0.036723547)\end{array}$ \\
\hline INCOME & & & & $\begin{array}{c}0.2068876613 * * * \\
(0.0326007962)\end{array}$ & $\begin{array}{l}0.2989196441 * * * * \\
(0.052609696)\end{array}$ \\
\hline ONLINE*AGE & & & & & $\begin{array}{l}-0.005427218^{*} \\
(0.0032382626)\end{array}$ \\
\hline ONLINE*PARTNER & & & & & $\begin{array}{l}-0.041356839 \\
(0.095416862)\end{array}$ \\
\hline ONLINE*GENDER & & & & & $\begin{array}{c}-0.033026714 \\
(0.0865145606)\end{array}$ \\
\hline ONLINE*SOCIABILITY & & & & & $\begin{array}{c}-0.02540055 \\
(0.0187191184)\end{array}$ \\
\hline ONLINE*INCOME & & & & & $\begin{array}{c}-0.050257082^{* * *} \\
(0.0250608908)\end{array}$ \\
\hline Observations & 1332 & 1332 & 1332 & 1332 & 1332 \\
\hline$-2 \log \mathrm{L}$ & 4934.169 & 4911.716 & 4693.866 & 4533.943 & 4523.396 \\
\hline $\begin{array}{l}\% \text { of values predicted } \\
\text { correctly }\end{array}$ & 58.8 & 60.4 & 68.1 & 71.9 & 72.1 \\
\hline
\end{tabular}

Note: $* * *$ coefficients significant at $1 \%, * *$ significant at $5 \%, *$ significant at $10 \%$ 
Table 3: The determinants of life satisfaction (Instrumental variables (2SLS) regression)

\begin{tabular}{|c|c|c|c|c|}
\hline \multicolumn{5}{|c|}{ Dependant variable: LIFE SATISFACTION } \\
\hline & 1 & 2 & 3 & 4 \\
\hline ONLINEINTENSE & $\begin{array}{c}0.8907 * * * \\
(0.2612482) \\
\end{array}$ & $\begin{array}{c}0.8260691 * * * \\
(0.2689595) \\
\end{array}$ & $\begin{array}{c}0.5124514 * * \\
(0.2482574) \\
\end{array}$ & $\begin{array}{c}0.2428203 \\
(0.2319105) \\
\end{array}$ \\
\hline AGE & $\begin{array}{c}-0.043933 * * \\
(0.021956)\end{array}$ & $\begin{array}{c}-0.0465341 * * \\
(0.0217177) \\
\end{array}$ & $\begin{array}{l}-0.035878^{*} \\
(0.0195119) \\
\end{array}$ & $\begin{array}{l}-0.0233804 \\
(0.0181956) \\
\end{array}$ \\
\hline AGESQUARED & $\begin{array}{c}0.0007919 * * * \\
(0.0002379)\end{array}$ & $\begin{array}{c}0.0008074 * * * \\
(0.0002361) \\
\end{array}$ & $\begin{array}{c}0.0005907 * * * \\
(0.0002134) \\
\end{array}$ & $\begin{array}{l}0.0003856^{*} \\
(0.0001988)\end{array}$ \\
\hline PARTNER & $\begin{array}{c}0.581665 * * * \\
(0.135151)\end{array}$ & $\begin{array}{c}0.6067608^{* * * *} \\
(0.1328239)\end{array}$ & $\begin{array}{c}0.4900372 * * * \\
(0.1197562)\end{array}$ & $\begin{array}{c}0.3228791 \text { *** } \\
(0.121449)\end{array}$ \\
\hline GENDER & $\begin{array}{c}-0.0308568 \\
(0.1304146) \\
\end{array}$ & $\begin{array}{l}-0.0606365 \\
(0.1270681) \\
\end{array}$ & $\begin{array}{c}0.0489562 \\
(0.1143332) \\
\end{array}$ & $\begin{array}{c}0.0901092 \\
(0.1065275) \\
\end{array}$ \\
\hline PRIMARY EDUCATION & $\begin{array}{c}0.231089 \\
(0.1950818) \\
\end{array}$ & $\begin{array}{c}0.247774 \\
(0.1938936) \\
\end{array}$ & $\begin{array}{c}0.1780095 \\
(0.1728283) \\
\end{array}$ & $\begin{array}{c}0.0993949 \\
(0.1605614) \\
\end{array}$ \\
\hline SECONDARY EDUCATION & REF. & REF. & REF. & REF. \\
\hline TERTIARY EDUCATION STAGE 1 & $\begin{array}{l}-0.1728339 \\
(0.2172944)\end{array}$ & $\begin{array}{l}-0.2052724 \\
(0.2138324) \\
\end{array}$ & $\begin{array}{l}-0.0702623 \\
(0.1934466)\end{array}$ & $\begin{array}{l}-0.0492058 \\
(0.1794798)\end{array}$ \\
\hline TERTIARY EDUCATION STAGE 2 & $\begin{array}{l}-0.668432 * * \\
(0.2851515) \\
\end{array}$ & $\begin{array}{c}-0.6059781 * * \\
(0.2860585) \\
\end{array}$ & $\begin{array}{l}-0.4919357^{*} \\
(0.2561929) \\
\end{array}$ & $\begin{array}{l}-0.3680346 \\
(0.2380638)\end{array}$ \\
\hline FULLTIMEJOB & $\begin{array}{c}0.0537686 \\
(0.1545132) \\
\end{array}$ & $\begin{array}{c}0.0461247 \\
(0.1534597) \\
\end{array}$ & $\begin{array}{c}0.0123572 \\
(0.1374577) \\
\end{array}$ & $\begin{array}{c}-0.1308015 \\
(0.1282265) \\
\end{array}$ \\
\hline PARTTIMEJOB & $\begin{array}{c}-0.5648791 * * \\
(0.2211529) \\
\end{array}$ & $\begin{array}{c}-0.5696832 * * * \\
(0.2186518) \\
\end{array}$ & $\begin{array}{c}-0.5050071 * * * * \\
(0.1959883) \\
\end{array}$ & $\begin{array}{c}-0.5559411 * * * \\
(0.1820476) \\
\end{array}$ \\
\hline NOACTIVITY & REF. & REF. & REF. & REF. \\
\hline MEMBERSHIP & & $\begin{array}{c}0.023921 \\
(0.0417694) \\
\end{array}$ & $\begin{array}{l}-0.0014826 \\
(0.0375066) \\
\end{array}$ & $\begin{array}{l}-0.0064392 \\
(0.0348442) \\
\end{array}$ \\
\hline VOLUNTEER & & $\begin{array}{c}0.0677025 \\
(0.0427021) \\
\end{array}$ & $\begin{array}{c}0.0771458 * * \\
(0.0383755) \\
\end{array}$ & $\begin{array}{c}0.0699086 * * \\
(0.0356148) \\
\end{array}$ \\
\hline SOCIABILITY & & $\begin{array}{l}0.0357124 \\
(0.031509) \\
\end{array}$ & $\begin{array}{c}0.0340343 \\
(0.0285056) \\
\end{array}$ & $\begin{array}{c}0.0379252 \\
(0.0264498) \\
\end{array}$ \\
\hline TRUSTOTHER & & & $\begin{array}{c}0.1188075^{* * *} * \\
(0.0239002) \\
\end{array}$ & $\begin{array}{c}0.079715^{* * * *} \\
(0.0223966)\end{array}$ \\
\hline GOD & & & $\begin{array}{c}0.0013254 \\
(0.1137442)\end{array}$ & $\begin{array}{l}-0.0214779 \\
(0.1056657)\end{array}$ \\
\hline FREEDOM & & & $\begin{array}{c}0.2639007 * * * \\
(0.0228525)\end{array}$ & $\begin{array}{c}0.2206101^{* * * *} \\
(0.0214806)\end{array}$ \\
\hline FAIRNESS & & & $\begin{array}{c}-0.0440452 * * \\
(0.0200081) \\
\end{array}$ & $\begin{array}{c}-0.0369567 * * \\
(0.0185687) \\
\end{array}$ \\
\hline TRUSTINSTITUTION & & & $\begin{array}{c}0.0359465 * * \\
(0.0156147) \\
\end{array}$ & $\begin{array}{c}0.0307613^{* *} \\
(0.0145279) \\
\end{array}$ \\
\hline HEALTH & & & & $\begin{array}{c}0.2900177 * * * \\
(0.034241)\end{array}$ \\
\hline INCOME & & & & $\begin{array}{c}0.1853691 * * * \\
(0.0310659)\end{array}$ \\
\hline Constant & $\begin{array}{c}6.210877 * * * \\
(0.7660976) \\
\end{array}$ & $\begin{array}{c}6.006432 * * * \\
(0.7100558) \\
\end{array}$ & $\begin{array}{c}4.080517 * * * \\
(0.6943842) \\
\end{array}$ & $\begin{array}{c}2.622325 * * * \\
(0.6565404) \\
\end{array}$ \\
\hline \multicolumn{5}{|c|}{ Instrumented: ONLINEINTENSE (Instrument variable: FAMILYINTERNET) } \\
\hline Observations & 1332 & 1332 & 1332 & 1332 \\
\hline $\begin{array}{l}\text { First-stage regression } \\
\mathrm{F}(3,1320) \quad \text { Prob }>\mathrm{F}\end{array}$ & $\begin{array}{l}74.4623 \\
(0.0000) \\
\end{array}$ & $\begin{array}{l}69.3893 \\
(0.0000)\end{array}$ & $\begin{array}{l}65.5453 \\
(0.0000)\end{array}$ & $\begin{array}{l}64.5768 \\
(0.0000)\end{array}$ \\
\hline Durbin (score) chi2(1) & $\begin{array}{c}8.61068 \\
(p=0.0033)\end{array}$ & $\begin{array}{c}7.33557 \\
(p=0.0068)\end{array}$ & $\begin{array}{c}2.9363 \\
(p=0.0866)\end{array}$ & $\begin{array}{c}0.460862 \\
(\mathrm{p}=0.4972)\end{array}$ \\
\hline Wu-Hausman F(1,1321) & $\begin{array}{c}8.58863 \\
(p=0.0034)\end{array}$ & $\begin{array}{c}7.29313 \\
(p=0.0070)\end{array}$ & $\begin{array}{c}2.8986 \\
(\mathrm{p}=0.0889)\end{array}$ & $\begin{array}{c}0.453407 \\
(\mathrm{p}=0.5008)\end{array}$ \\
\hline
\end{tabular}




\section{APPENDIX}

Table 4: The determinants of life satisfaction (ordinary least square model)

\begin{tabular}{|c|c|c|c|c|c|}
\hline \multicolumn{6}{|c|}{ Dependant variable: LIFE SATISFACTION } \\
\hline & 1 & 2 & 3 & 4 & 5 \\
\hline ONLINEDAY+ & $\begin{array}{c}-0.002347103 \\
(0.1681293028) \\
\end{array}$ & $\begin{array}{c}-0.01365192 \\
(0.1671923207)\end{array}$ & $\begin{array}{c}-0.114838919 \\
(0.1549876555)\end{array}$ & $\begin{array}{c}-0.068667081 \\
(0.1467623727) \\
\end{array}$ & $\begin{array}{c}1.0621516114 * * * * \\
(0.4014631458)\end{array}$ \\
\hline ONLINEDAY & $\begin{array}{l}-0.114233825 \\
(0.176272498) \\
\end{array}$ & $\begin{array}{l}-0.146138482 \\
(0.175180888) \\
\end{array}$ & $\begin{array}{c}-0.166683148 \\
(0.1619500498) \\
\end{array}$ & $\begin{array}{c}-0.136517589 \\
(0.1533312389) \\
\end{array}$ & $\begin{array}{c}0.4246866723 * \\
(0.240301401) \\
\end{array}$ \\
\hline ONLINEMONTH & REF. & REF. & REF. & REF. & REF. \\
\hline NOINTERNET & $\begin{array}{c}-0.734322327 * * * \\
(0.1916535968)\end{array}$ & $\begin{array}{c}-0.628545742 * * * \\
(0.1916641479)\end{array}$ & $\begin{array}{c}-0.600347902 * * * \\
(0.1781073657)\end{array}$ & $\begin{array}{l}-0.46720322 * * * \\
(0.1689411411) \\
\end{array}$ & $\begin{array}{c}-1.166506095 * * * \\
(0.2813965595)\end{array}$ \\
\hline AGE & $\begin{array}{c}-0.047713752 * * \\
(0.020792678) \\
\end{array}$ & $\begin{array}{l}-0.048443525^{* *} \\
(0.0207259191) \\
\end{array}$ & $\begin{array}{c}-0.03644524 * \\
(0.0191865624) \\
\end{array}$ & $\begin{array}{c}-0.023419595 \\
(0.0182549072) \\
\end{array}$ & $\begin{array}{c}0.0024754714 \\
(0.0216509794) \\
\end{array}$ \\
\hline AGESQUARED & $\begin{array}{c}0.0006668173 * * * \\
(0.0002202867)\end{array}$ & $\begin{array}{c}0.0006776478 * * * \\
(0.0002191265)\end{array}$ & $\begin{array}{c}0.0005177954 * * \\
(0.0002030634)\end{array}$ & $\begin{array}{l}0.0003650176^{*} \\
(0.0001926979)\end{array}$ & $\begin{array}{c}0.0001912253 \\
(0.0002062479)\end{array}$ \\
\hline PARTNER & $\begin{array}{c}0.5033415921 * * * \\
(0.1262784685)\end{array}$ & $\begin{array}{c}0.5475982364 * * * \\
(0.1257949218) \\
\end{array}$ & $\begin{array}{c}0.4531968019 * * * \\
(0.1169604579) \\
\end{array}$ & $\begin{array}{c}0.3047906412 * * * \\
(0.1115721499) \\
\end{array}$ & $\begin{array}{c}0.3588964496^{*} \\
(0.195935581) \\
\end{array}$ \\
\hline GENDER & $\begin{array}{c}0.1292228392 \\
(0.1153927923)\end{array}$ & $\begin{array}{c}0.0669177456 \\
(0.1154696538)\end{array}$ & $\begin{array}{c}0.1281179883 \\
(0.1077806785)\end{array}$ & $\begin{array}{c}0.126750481 \\
(0.1023048799)\end{array}$ & $\begin{array}{c}0.2385361969 \\
(0.1774796205)\end{array}$ \\
\hline $\begin{array}{l}\text { PRIMARY } \\
\text { EDUCATION }\end{array}$ & $\begin{array}{c}-0.099892936 \\
(0.1368044286) \\
\end{array}$ & $\begin{array}{c}-0.065012762 \\
(0.1365130598) \\
\end{array}$ & $\begin{array}{c}0.0102298694 \\
(0.1266768861) \\
\end{array}$ & $\begin{array}{c}0.0448920346 \\
(0.1199519923) \\
\end{array}$ & $\begin{array}{c}0.0477532539 \\
(0.1197568311) \\
\end{array}$ \\
\hline $\begin{array}{l}\text { SECONDARY } \\
\text { EDUCATION }\end{array}$ & REF. & REF. & REF. & REF. & REF \\
\hline $\begin{array}{l}\text { TERTIARY } \\
\text { EDUCATION STAGE } 1\end{array}$ & $\begin{array}{l}0.1353575762 \\
(0.174177701)\end{array}$ & $\begin{array}{l}0.0722663061 \\
(0.173554204)\end{array}$ & $\begin{array}{c}0.0914379249 \\
(0.1613024774)\end{array}$ & $\begin{array}{c}0.0061014852 \\
(0.1528936292)\end{array}$ & $\begin{array}{c}0.0162948802 \\
(0.1530067086)\end{array}$ \\
\hline $\begin{array}{l}\text { TERTIARY } \\
\text { EDUCATION STAGE } 2\end{array}$ & $\begin{array}{c}-0.036035438 \\
(0.1773773433) \\
\end{array}$ & $\begin{array}{c}-0.020924376 \\
(0.1763086834)\end{array}$ & $\begin{array}{c}-0.139158935 \\
(0.1634499219)\end{array}$ & $\begin{array}{c}-0.228239325 \\
(0.1548996608)\end{array}$ & $\begin{array}{c}-0.200172979 \\
(0.1550580329)\end{array}$ \\
\hline FULLTIMEJOB & $\begin{array}{c}0.0112184641 \\
(0.1465268511) \\
\end{array}$ & $\begin{array}{c}-0.0092449 \\
(0.1459497456) \\
\end{array}$ & $\begin{array}{c}-0.024304429 \\
(0.1348154162) \\
\end{array}$ & $\begin{array}{c}-0.151112913 \\
(0.1281454686) \\
\end{array}$ & $\begin{array}{c}-0.130278791 \\
(0.1292037719) \\
\end{array}$ \\
\hline PARTTIMEJOB & $\begin{array}{c}-0.743081209 * * * \\
(0.206875626) \\
\end{array}$ & $\begin{array}{c}-0.734960177 * * * \\
(0.2054157696) \\
\end{array}$ & $\begin{array}{c}-0.625594761 * * * \\
(0.1896945358) \\
\end{array}$ & $\begin{array}{c}-0.621642547 * * * \\
(0.1797681333) \\
\end{array}$ & $\begin{array}{l}-0.6027106 * * * \\
(0.1796354827) \\
\end{array}$ \\
\hline NOACTIVITY & REF. & REF. & REF. & REF. & REF. \\
\hline MEMBERSHIP & & $\begin{array}{c}0.0169681979 \\
(0.0398145422) \\
\end{array}$ & $\begin{array}{c}-0.005937057 \\
(0.0368294336) \\
\end{array}$ & $\begin{array}{c}-0.007905085 \\
(0.0348983919) \\
\end{array}$ & $\begin{array}{c}-0.009293941 \\
(0.0348597054) \\
\end{array}$ \\
\hline VOLUNTEER & & $\begin{array}{l}0.069131005^{*} \\
(0.040757839) \\
\end{array}$ & $\begin{array}{l}0.076149008 * * \\
(0.0377262984) \\
\end{array}$ & $\begin{array}{l}0.0682511901^{*} \\
(0.0357215609) \\
\end{array}$ & $\begin{array}{l}0.0689127809^{*} \\
(0.0357871137) \\
\end{array}$ \\
\hline SOCIABILITY & & $\begin{array}{c}0.0737094095 * * * \\
(0.0258700341) \\
\end{array}$ & $\begin{array}{c}0.055104825 * * \\
(0.023962523) \\
\end{array}$ & $\begin{array}{c}0.044463191 * \\
(0.0227024261) \\
\end{array}$ & $\begin{array}{c}0.0670506488 * \\
(0.037135078) \\
\end{array}$ \\
\hline TRUSTOTHER & & & $\begin{array}{c}0.1185571708 * * * \\
(0.023448288) \\
\end{array}$ & $\begin{array}{c}0.0783878533 * * * * \\
(0.0224366621) \\
\end{array}$ & $\begin{array}{c}0.0724020973 * * * \\
(0.0225808734) \\
\end{array}$ \\
\hline GOD & & & $\begin{array}{c}-0.053297615 \\
(0.1072761513) \\
\end{array}$ & $\begin{array}{c}-0.042332682 \\
(0.1017207543) \\
\end{array}$ & $\begin{array}{c}-0.051933051 \\
(0.1017038851) \\
\end{array}$ \\
\hline FREEDOM & & & $\begin{array}{c}0.2685674977 * * * \\
(0.0223735515) \\
\end{array}$ & $\begin{array}{c}0.2227665278 * * * \\
(0.0215014272) \\
\end{array}$ & $\begin{array}{c}0.2207151121 * * * \\
(0.0214846098) \\
\end{array}$ \\
\hline FAIRNESS & & & $\begin{array}{c}-0.051954809 * * * \\
(0.0189901155) \\
\end{array}$ & $\begin{array}{c}-0.039622346 * * \\
(0.0180042954) \\
\end{array}$ & $\begin{array}{c}-0.045746715^{* *} \\
(0.0180993309) \\
\end{array}$ \\
\hline TRUSTINSTITUTION & & & $\begin{array}{c}0.0417125836^{* * * *} \\
(0.0154292051)\end{array}$ & $\begin{array}{c}0.0347723315 * * \\
(0.0146512694)\end{array}$ & $\begin{array}{c}0.0372280827 * * \\
(0.0146573393)\end{array}$ \\
\hline HEALTH & & & & $\begin{array}{c}0.2880794635 * * * \\
(0.0343297535)\end{array}$ & $\begin{array}{c}0.289810959 * * * \\
(0.034384363)\end{array}$ \\
\hline INCOME & & & & $\begin{array}{c}0.1852046377 * * * \\
(0.0310537227) \\
\end{array}$ & $\begin{array}{c}0.2555693438 * * * \\
(0.0498931671) \\
\end{array}$ \\
\hline ONLINE*AGE & & & & & $\begin{array}{c}-0.005982785^{*} \\
(0.0030769024)\end{array}$ \\
\hline ONLINE*PARTNER & & & & & $\begin{array}{c}-0.018474626 \\
(0.0909273204) \\
\end{array}$ \\
\hline ONLINE*GENDER & & & & & $\begin{array}{c}-0.060369764 \\
(0.082229557) \\
\end{array}$ \\
\hline ONLINE*SOCIABILITY & & & & & $\begin{array}{c}-0.014615491 \\
(0.0177724529) \\
\end{array}$ \\
\hline ONLINE*INCOME & & & & & $\begin{array}{l}-0.041505327 * \\
(0.0239250549) \\
\end{array}$ \\
\hline Constant & $\begin{array}{c}8.3742534065 * * * \\
(0.4254385543)\end{array}$ & $\begin{array}{c}7.7903703611 * * * \\
(0.4509770945)\end{array}$ & $\begin{array}{c}5.2730574771 * * * \\
(0.4770345235)\end{array}$ & $\begin{array}{c}3.2342779575 * * * \\
(0.4838385718)\end{array}$ & $\begin{array}{c}2.5690242747 * * * \\
(0.5309907079)\end{array}$ \\
\hline Observations & 1332 & 1332 & 1332 & 1332 & 1332 \\
\hline Adj. R-Square & 0.0525 & 0.0663 & 0.2057 & 0.2882 & 0.2912 \\
\hline
\end{tabular}

\footnotetext{
Note: $* * *$ coefficients significant at $1 \%$, ** significant at $5 \%$, significant at $10 \%$
} 
Table 5: The determinants of happiness (ordered logit model)

\begin{tabular}{|c|c|c|c|c|c|}
\hline \multicolumn{6}{|c|}{ Dependant variable: HAPPINESS } \\
\hline & 1 & 2 & 3 & 4 & 5 \\
\hline ONLINEDAY+ & $\begin{array}{c}0.1537496123 \\
(0.1700396591)\end{array}$ & $\begin{array}{c}0.1520480987 \\
(0.1708353618)\end{array}$ & $\begin{array}{c}0.0818862904 \\
(0.1746138535)\end{array}$ & $\begin{array}{c}0.1372920204 \\
(0.1768550625)\end{array}$ & $\begin{array}{c}0.766873353 \\
(0.4939740687)\end{array}$ \\
\hline ONLINEDAY & $\begin{array}{c}-0.094316054 \\
(0.1787215964)\end{array}$ & $\begin{array}{c}-0.110283958 \\
(0.179381176) \\
\end{array}$ & $\begin{array}{c}-0.146010137 \\
(0.1825979503)\end{array}$ & $\begin{array}{c}-0.113701629 \\
(0.1852371876)\end{array}$ & $\begin{array}{c}0.1926788278 \\
(0.2944365595) \\
\end{array}$ \\
\hline ONLINEMONTH & REF. & REF. & REF. & REF. & REF. \\
\hline NOINTERNET & $\begin{array}{c}-0.374901404^{*} \\
(0.1957604804)\end{array}$ & $\begin{array}{c}-0.312619854 \\
(0.1975536859)\end{array}$ & $\begin{array}{c}-0.343483897^{*} \\
(0.2023210878)\end{array}$ & $\begin{array}{c}-0.236857524 \\
(0.2049011268)\end{array}$ & $\begin{array}{c}-0.689661094 * * \\
(0.3457735697)\end{array}$ \\
\hline AGE & $\begin{array}{c}-0.079702031 * * * \\
(0.0213181028)\end{array}$ & $\begin{array}{c}-0.081395628 * * * \\
(0.0214892545)\end{array}$ & $\begin{array}{c}-0.073909723 * * * * \\
(0.0218262911)\end{array}$ & $\begin{array}{c}-0.060178209 * * * \\
(0.022245933) \\
\end{array}$ & $\begin{array}{c}-0.041599342 \\
(0.0262950275)\end{array}$ \\
\hline AGESQUARED & $\begin{array}{c}0.0008045357 * * * * \\
(0.0002256231)\end{array}$ & $\begin{array}{c}0.0008224167 * * * \\
(0.000227064)\end{array}$ & $\begin{array}{c}0.0007071878 * * * \\
(0.0002305611)\end{array}$ & $\begin{array}{c}0.0005522868 * * \\
(0.0002344213)\end{array}$ & $\begin{array}{c}0.0004412475^{*} \\
(0.000250159)\end{array}$ \\
\hline PARTNER & $\begin{array}{c}0.8215312625 * * * \\
(0.1319330594) \\
\end{array}$ & $\begin{array}{c}0.8547144171 * * * \\
(0.1329054499) \\
\end{array}$ & $\begin{array}{c}0.8257344145 * * * \\
(0.1354412352) \\
\end{array}$ & $\begin{array}{r}0.731201241 * * * \\
(0.1379011458) \\
\end{array}$ & $\begin{array}{c}0.8999719592 * * * \\
(0.244222205) \\
\end{array}$ \\
\hline GENDER & $\begin{array}{l}-0.226986006^{*} \\
(0.1176155887) \\
\end{array}$ & $\begin{array}{c}-0.264607025 * * \\
(0.1189792273) \\
\end{array}$ & $\begin{array}{c}-0.26602533^{* *} \\
(0.122302547)\end{array}$ & $\begin{array}{c}-0.28032867 * * \\
(0.1245156799)\end{array}$ & $\begin{array}{c}-0.105979794 \\
(0.2170093966) \\
\end{array}$ \\
\hline $\begin{array}{l}\text { PRIMARY } \\
\text { EDUCATION }\end{array}$ & $\begin{array}{c}-0.029385324 \\
(0.1392946464) \\
\end{array}$ & $\begin{array}{c}-0.007661238 \\
(0.1403353174) \\
\end{array}$ & $\begin{array}{c}0.0204207486 \\
(0.1433833062) \\
\end{array}$ & $\begin{array}{c}0.0621772918 \\
(0.1457428595) \\
\end{array}$ & $\begin{array}{c}0.0634400549 \\
(0.1459759676) \\
\end{array}$ \\
\hline $\begin{array}{l}\text { SECONDARY } \\
\text { EDUCATION }\end{array}$ & REF. & REF. & REF. & REF. & REF \\
\hline $\begin{array}{l}\text { TERTIARY } \\
\text { EDUCATION STAGE } 1\end{array}$ & $\begin{array}{l}0.2892598562 * \\
(0.1756718693)\end{array}$ & $\begin{array}{c}0.2486349499 \\
(0.176707768) \\
\end{array}$ & $\begin{array}{c}0.2183053861 \\
(0.1817004763) \\
\end{array}$ & $\begin{array}{c}0.1558158963 \\
(0.1842506278) \\
\end{array}$ & $\begin{array}{c}0.1551450691 \\
(0.1849499295) \\
\end{array}$ \\
\hline $\begin{array}{l}\text { TERTIARY } \\
\text { EDUCATION STAGE } 2\end{array}$ & $\begin{array}{c}-0.029689888 \\
(0.1795877089) \\
\end{array}$ & $\begin{array}{c}-0.011120325 \\
(0.1803249526)\end{array}$ & $\begin{array}{c}-0.126319689 \\
(0.1839275111) \\
\end{array}$ & $\begin{array}{c}-0.227808196 \\
(0.1870931736)\end{array}$ & $\begin{array}{c}-0.218648039 \\
(0.1877237583) \\
\end{array}$ \\
\hline FULLTIMEJOB & $\begin{array}{c}0.1827354689 \\
(0.1489523417)\end{array}$ & $\begin{array}{c}0.1762928231 \\
(0.1497946345)\end{array}$ & $\begin{array}{c}0.1576646483 \\
(0.1523677056)\end{array}$ & $\begin{array}{c}0.0456055161 \\
(0.1552309076)\end{array}$ & $\begin{array}{c}0.0506777743 \\
(0.1569706782)\end{array}$ \\
\hline PARTTIMEJOB & $\begin{array}{c}-0.198938949 \\
(0.211974135) \\
\end{array}$ & $\begin{array}{l}-0.195941679 \\
(0.212464153) \\
\end{array}$ & $\begin{array}{c}-0.170827492 \\
(0.2157967907) \\
\end{array}$ & $\begin{array}{c}-0.216366899 \\
(0.2184675805) \\
\end{array}$ & $\begin{array}{c}-0.206279584 \\
(0.2190510768) \\
\end{array}$ \\
\hline NOACTIVITY & REF. & REF. & REF. & REF. & REF. \\
\hline MEMBERSHIP & & $\begin{array}{c}-0.004857606 \\
(0.0407205446)\end{array}$ & $\begin{array}{c}-0.014049023 \\
(0.0415916006)\end{array}$ & $\begin{array}{c}-0.014646105 \\
(0.0423493807)\end{array}$ & $\begin{array}{l}-0.016396919 \\
(0.04238002)\end{array}$ \\
\hline VOLUNTEER & & $\begin{array}{l}0.0736750255^{*} \\
(0.0416516329)\end{array}$ & $\begin{array}{l}0.0821414074 * \\
(0.0425057508)\end{array}$ & $\begin{array}{l}0.0794419866^{*} \\
(0.0431625609)\end{array}$ & $\begin{array}{l}0.0846299423 * \\
(0.0433718169)\end{array}$ \\
\hline SOCIABILITY & & $\begin{array}{c}0.0342415637 \\
(0.0266001893) \\
\end{array}$ & $\begin{array}{c}0.0199204982 \\
(0.0272136057) \\
\end{array}$ & $\begin{array}{c}0.0098331843 \\
(0.0275973948) \\
\end{array}$ & $\begin{array}{c}0.0242870627 \\
(0.0454704724) \\
\end{array}$ \\
\hline TRUSTOTHER & & & $\begin{array}{c}0.1163980697 * * * \\
(0.0267750254) \\
\end{array}$ & $\begin{array}{c}0.0824739005^{* * * *} \\
(0.027341015) \\
\end{array}$ & $\begin{array}{c}0.0799245185 * * * \\
(0.0275900808) \\
\end{array}$ \\
\hline GOD & & & $\begin{array}{c}0.0271541019 \\
(0.1213700436) \\
\end{array}$ & $\begin{array}{c}0.0256321211 \\
(0.1233561987) \\
\end{array}$ & $\begin{array}{c}0.0195166448 \\
(0.1237059103) \\
\end{array}$ \\
\hline FREEDOM & & & $\begin{array}{c}0.109842892 * * * \\
(0.0257077335)\end{array}$ & $\begin{array}{c}0.075068348 * * * \\
(0.0262661139)\end{array}$ & $\begin{array}{c}0.0741937823 \text { *** } \\
(0.0263290998)\end{array}$ \\
\hline FAIRNESS & & & $\begin{array}{c}-0.054765159^{* * *} \\
(0.0216279651) \\
\end{array}$ & $\begin{array}{c}-0.044843879 * * \\
(0.0219264206) \\
\end{array}$ & $\begin{array}{c}-0.050191087 * * \\
(0.022103205) \\
\end{array}$ \\
\hline TRUSTINSTITUTION & & & $\begin{array}{c}0.0693060213 * * * \\
(0.0175681908) \\
\end{array}$ & $\begin{array}{c}0.0672511107 * * * \\
(0.0179124446)\end{array}$ & $\begin{array}{c}0.0685749353^{*} * * \\
(0.0179854466) \\
\end{array}$ \\
\hline HEALTH & & & & $\begin{array}{c}0.3113334837 \text { **** } \\
(0.0439228617)\end{array}$ & $\begin{array}{c}0.3130478357 \text { *** } \\
(0.0441129133)\end{array}$ \\
\hline INCOME & & & & $\begin{array}{c}0.1349741077 * * * \\
(0.0382670233) \\
\end{array}$ & $\begin{array}{c}0.1252591892 * * \\
(0.0619795176) \\
\end{array}$ \\
\hline ONLINE*AGE & & & & & $\begin{array}{c}-0.004815832 \\
(0.0037342963)\end{array}$ \\
\hline ONLINE*PARTNER & & & & & $\begin{array}{c}-0.085116948 \\
(0.1117761285) \\
\end{array}$ \\
\hline ONLINE*GENDER & & & & & $\begin{array}{c}-0.09783174 \\
(0.1003099213)\end{array}$ \\
\hline ONLINE*SOCIABILITY & & & & & $\begin{array}{c}-0.010300391 \\
(0.0217139451)\end{array}$ \\
\hline ONLINE*INCOME & & & & & $\begin{array}{c}0.0071578257 \\
(0.0295505962)\end{array}$ \\
\hline Observations & 1332 & 1332 & 1332 & 1332 & 1332 \\
\hline$-2 \log \mathrm{L}$ & 2192.790 & 2183.410 & 2105.239 & 2018.180 & 2014.150 \\
\hline $\begin{array}{l}\% \text { of values predicted } \\
\text { correctly }\end{array}$ & 60.9 & 61.7 & 66.9 & 71.0 & 71.0 \\
\hline
\end{tabular}

Note: $* * *$ coefficients significant at $1 \%, * *$ significant at $5 \%, *$ significant at $10 \%$ 
Table 6: Determinants of the instrument (probability that most of family members use the Internet)- Logit model

\begin{tabular}{|c|c|}
\hline & FAMILYINTERNET \\
\hline AGE & $\begin{array}{c}0.0141411701 \\
(0.0286354122)\end{array}$ \\
\hline AGESQUARED & $\begin{array}{c}-0.000237259 \\
(0.0002974515)\end{array}$ \\
\hline PARTNER & $\begin{array}{c}0.3730396966 * * \\
(0.183216011) \\
\end{array}$ \\
\hline GENDER & $\begin{array}{c}-0.209166262 \\
(0.1700985161)\end{array}$ \\
\hline PRIMARY EDUCATION & $\begin{array}{c}-0.472099647 * * * * \\
(0.1768914893) \\
\end{array}$ \\
\hline $\begin{array}{l}\text { TERTIARY EDUCATION } \\
\text { STAGE } 1\end{array}$ & $\begin{array}{l}1.067727679 * * * \\
(0.3569843129) \\
\end{array}$ \\
\hline $\begin{array}{l}\text { TERTIARY EDUCATION } \\
\text { STAGE } 2\end{array}$ & $\begin{array}{c}1.3369936839 * * * \\
(0.372361015)\end{array}$ \\
\hline FULLTIMEJOB & $\begin{array}{c}-0.222238242 \\
(0.2109074372)\end{array}$ \\
\hline PARTTIMEJOB & $\begin{array}{c}-0.271405498 \\
(0.2856159827)\end{array}$ \\
\hline MEMBERSHIP & $\begin{array}{l}-0.031199357 \\
(0.060717065)\end{array}$ \\
\hline VOLUNTEER & $\begin{array}{c}0.0732592148 \\
(0.0640163618) \\
\end{array}$ \\
\hline SOCIABILITY & $\begin{array}{l}0.0604634558^{*} \\
(0.0366387836)\end{array}$ \\
\hline TRUSTOTHER & $\begin{array}{r}0.0777530703 * * \\
(0.0360293642) \\
\end{array}$ \\
\hline GOD & $\begin{array}{c}-0.292543851 \\
(0.1788011252)\end{array}$ \\
\hline FREEDOM & $\begin{array}{c}0.0359660595 \\
(0.0339773829) \\
\end{array}$ \\
\hline FAIRNESS & $\begin{array}{c}-0.002777672 \\
(0.0287032406) \\
\end{array}$ \\
\hline TRUSTINSTITUTION & $\begin{array}{c}-0.007537265 \\
(0.0233765862)\end{array}$ \\
\hline HEALTH & $\begin{array}{l}0.1100128485 * * \\
(0.0518358332) \\
\end{array}$ \\
\hline INCOME & $\begin{array}{c}0.0718507448 \\
(0.0488607328)\end{array}$ \\
\hline Observations & 1332 \\
\hline$-2 \log \mathrm{L}$ & 1037.877 \\
\hline$\%$ of values predicted correctly & 72.7 \\
\hline
\end{tabular}

Note: $* * *$ coefficients significant at $1 \%, * *$ significant at $5 \%$, significant at $10 \%$ 
Table 7: The determinants of Internet use (First stage Instrumental variables (2SLS) regression)

\begin{tabular}{|c|c|c|c|c|}
\hline & $\begin{array}{c}\text { First-stage of } \\
\text { model } 1\end{array}$ & $\begin{array}{c}\text { First-stage of } \\
\text { model } 2\end{array}$ & $\begin{array}{c}\text { First-stage of } \\
\text { model } 3\end{array}$ & $\begin{array}{c}\text { First-stage of } \\
\text { model } 4\end{array}$ \\
\hline AGE & $\begin{array}{r}-0.0062349 \\
(0.009716) \\
\end{array}$ & $\begin{array}{l}-0.0040784 \\
(0.0096842)\end{array}$ & $\begin{array}{l}-0.0035406 \\
(0.0097037)\end{array}$ & $\begin{array}{l}-0.0036917 \\
(0.0097613)\end{array}$ \\
\hline AGESQUARED & $\begin{array}{l}-0.0001989 * \\
(0.0001027) \\
\end{array}$ & $\begin{array}{c}-0.0002057 * * \\
(0.0001021) \\
\end{array}$ & $\begin{array}{l}-.0002102 * * \\
(0.0001024) \\
\end{array}$ & $\begin{array}{c}-0.0002105^{* *} \\
(0.0001027) \\
\end{array}$ \\
\hline PARTNER & $\begin{array}{l}-.1246026^{* *} \\
(0.0590558) \\
\end{array}$ & $\begin{array}{l}-0.100527 * \\
(0.0588526) \\
\end{array}$ & $\begin{array}{c}-0.0915053 \\
(0.05923) \\
\end{array}$ & $\begin{array}{l}-0.0915527 \\
(0.0597011) \\
\end{array}$ \\
\hline GENDER & $\begin{array}{c}0.2038856 * * * \\
(0.053427) \\
\end{array}$ & $\begin{array}{c}0.1736257 * * * \\
(0.0534731) \\
\end{array}$ & $\begin{array}{c}0.1569495^{* * *} \\
(0.0540951) \\
\end{array}$ & $\begin{array}{c}0.1583093 * * * \\
(0.0542849) \\
\end{array}$ \\
\hline PRIMARY EDUCATION & $\begin{array}{c}0-.4611388^{* * * *} \\
(0.0623387)\end{array}$ & $\begin{array}{c}-0.4481456^{* * * *} \\
(0.0623111) \\
\end{array}$ & $\begin{array}{c}-0.4306628^{* * * *} \\
(0.0627191)\end{array}$ & $\begin{array}{c}-0.4300596^{* * * *} \\
(0.0627887) \\
\end{array}$ \\
\hline SECONDARY EDUCATION & REF. & REF. & REF. & REF. \\
\hline $\begin{array}{l}\text { TERTIARY EDUCATION } \\
\text { STAGE } 1\end{array}$ & $\begin{array}{c}0.3970519 * * * \\
(0.080685) \\
\end{array}$ & $\begin{array}{c}0.3766332 * * * \\
(0.0804054)\end{array}$ & $\begin{array}{c}0.3755747 * * * \\
(0.0808559 \\
\end{array}$ & $\begin{array}{c}0.3741371 * * \\
(0.0810135) \\
\end{array}$ \\
\hline $\begin{array}{l}\text { TERTIARY EDUCATION } \\
\text { STAGE } 2\end{array}$ & $\begin{array}{c}0.7801688 * * * \\
(0.0795372)\end{array}$ & $\begin{array}{c}0.7690725^{* * *} \\
(0.0791087)\end{array}$ & $\begin{array}{c}0.7485249 * * * \\
(0.0795109)\end{array}$ & $\begin{array}{c}0.747479 * * * \\
(0.0796436)\end{array}$ \\
\hline FULLTIMEJOB & $\begin{array}{l}-0.0211067 \\
(0.0684417) \\
\end{array}$ & $\begin{array}{l}-0.0436112 \\
(0.0681576) \\
\end{array}$ & $\begin{array}{l}-0.0357268 \\
(0.0681382) \\
\end{array}$ & $\begin{array}{l}-0.0379258 \\
(0.0684899) \\
\end{array}$ \\
\hline PARTTIMEJOB & $\begin{array}{r}-0.1402888 \\
(0.096227) \\
\end{array}$ & $\begin{array}{c}-0.143784 \\
(0.0955081) \\
\end{array}$ & $\begin{array}{l}-0.140962 \\
(0.0954485) \\
\end{array}$ & $\begin{array}{l}-0.1395419 \\
(0.0956255) \\
\end{array}$ \\
\hline NOACTIVITY & REF. & REF. & REF. & REF. \\
\hline MEMBERSHIP & & $\begin{array}{l}-0.0089648 \\
(0.0185948) \\
\end{array}$ & $\begin{array}{l}-0.0084124 \\
(0.0186155)\end{array}$ & $\begin{array}{c}-0.00872 \\
(0.0186478)\end{array}$ \\
\hline VOLUNTEER & & $\begin{array}{c}0.0020598 \\
(0.0190487) \\
\end{array}$ & $\begin{array}{c}0.0013346 \\
(0.0190872 \\
\end{array}$ & $\begin{array}{c}0.0011718 \\
(0.0191054) \\
\end{array}$ \\
\hline SOCIABILITY & & $\begin{array}{c}0.0558742 * * * \\
(0.0119814)\end{array}$ & $\begin{array}{c}0.0562015^{* * *} \\
(0.0120098)\end{array}$ & $\begin{array}{c}0.0560273^{* * * *} \\
(0.0120298)\end{array}$ \\
\hline TRUSTOTHER & & & $\begin{array}{c}0.0018529 \\
(0.0118716) \\
\end{array}$ & $\begin{array}{c}0.0015794 \\
(0.0120039) \\
\end{array}$ \\
\hline GOD & & & $\begin{array}{c}-0.1146838^{* *} \\
(0.0542092)\end{array}$ & $\begin{array}{l}-.1135418 * * \\
(0.0543405)\end{array}$ \\
\hline FREEDOM & & & $\begin{array}{c}0.0051339 \\
(0.0113227)\end{array}$ & $\begin{array}{l}0.0046616 \\
(0.011494)\end{array}$ \\
\hline FAIRNESS & & & $\begin{array}{c}-0.0206213 * * \\
(0.0095906)\end{array}$ & $\begin{array}{c}-.0204802 * * \\
(0.009613)\end{array}$ \\
\hline TRUSTINSTITUTION & & & $\begin{array}{c}0.0029434 \\
(0.0077632)\end{array}$ & $\begin{array}{c}0.0027062 \\
(0.0077917)\end{array}$ \\
\hline HEALTH & & & & $\begin{array}{c}-0.0019355 \\
(0.0183874) \\
\end{array}$ \\
\hline INCOME & & & & $\begin{array}{c}0.0066047 \\
(0.0166141) \\
\end{array}$ \\
\hline FAMILYINTERNET & $\begin{array}{c}0.6211553 * * * \\
(0.0719833)\end{array}$ & $\begin{array}{c}0.5970285^{* * *} * \\
(0.0716719)\end{array}$ & $\begin{array}{c}0.5830072 * * * \\
(0.0720117)\end{array}$ & $\begin{array}{c}0.5816337 * * * \\
(0.0723788)\end{array}$ \\
\hline Constant & $\begin{array}{c}1.900643 * * * \\
(0.199741)\end{array}$ & $\begin{array}{c}1.561786^{* * * *} \\
(0.2107654)\end{array}$ & $\begin{array}{c}1.658535 * * * \\
(0.2400006)\end{array}$ & $\begin{array}{c}1.651293 * * * \\
(0.2554907)\end{array}$ \\
\hline Observations & 1332 & 1332 & 1332 & 1332 \\
\hline Adj R-squared & 0.3847 & 0.3941 & 0.4043 & 0.3953 \\
\hline
\end{tabular}

